\title{
AUDIT OPERASIONAL ATAS SIKLUS PENDAPATAN PADA PT NEW INTI FURNINDO CABANG BANDUNG
}

\author{
Stefanus Ariyanto; Juli Yanti \\ Jurusan Akuntansi, Fakultas Ekonomi dan Komunikasi, BINUS University \\ Jln. K.H. Syahdan No. 9, Palmerah, Jakarta Barat 11480
}

\begin{abstract}
PT New Inti Furnindo Branch Bandung is a private company engaged in the knock-down furniture trade, which is a branch of the PT New Inti Furnindo Branch Jakarta. The products sold are produced centrally in Jakarta. The problems faced by this company are annual sales that never meet the targets set by the head quarter, the problems in the organizational structure and procedures of sales and cash receipts that are considered less effective and efficient in achieving corporate objectives. The method used to examine the issue is to do a descriptive analysis to compare the current condition with criteria or standards that should be implemented, examined data relating to the company's revenue cycle and then make direct observations on the implementation of sales procedures, and conduct interviews with officials related to findings. The results indicate that the sales target setting is not effective, the establishment of sales procedures and organizational structures that are inefficient. This condition will cause the company less economies, which in turn affect the company's going concern.
\end{abstract}

Keywords: auditing, operational audit, sales cycle

\begin{abstract}
ABSTRAK
PT New Inti Furnindo Cabang Bandung adalah perusahaan swasta yang bergerak dalam bidang perdagangan furnitur, dalam hal ini memasarkan dan menjual produk furnitur siap jual atau yang bersifat knock down (bongkar pasang), yang merupakan cabang dari PT New Inti Furnindo Jakarta. Produk yang dijual diproduksi secara terpusat di Jakarta. Permasalahan yang sedang dihadapi perusahaan ini adalah hasil penjualan tahunan yang tidak pernah dapat memenuhi target yang telah ditetapkan oleh perusahaan, permasalahan dalam struktur organisasi dan prosedur bagian penjualan serta penerimaan kas yang dianggap kurang efektif dan efisien dalam mencapai tujuan perusahaan. Metode yang digunakan untuk meneliti masalah tersebut adalah dengan melakukan analisa deskriptif dengan membandingkan antara kondisi yang sedang terjadi dengan kriteria atau standar yang seharusnya dilaksanakan, meneliti data perusahaan yang berkaitan dengan siklus pendapatan lalu melakukan pengamatan secara langsung atas pelaksanaan prosedur penjualan, dan melakukan wawancara dengan pejabat terkait agar dapat dikembangkan temuan yang menjelaskan sebab dan akibat yang timbul. Hasil penelitian menunjukkan adanya penetapan target penjualan yang tidak efektif, penetapan prosedur penjualan serta struktur organisasi yang tidak efisien. Kondisi ini akan menyebabkan perusahaan tidak ekonomis, yang pada akhirnya berpengaruh terhadap kelangsungan hidup perusahaan.
\end{abstract}

Kata kunci: auditing, audit operasional, siklus penjualan 


\section{PENDAHULUAN}

Audit operasional merupakan evaluasi atas berbagai kegiatan operasional perusahaan, sedangkan sasarannya adalah untuk menilai apakah pelaksanaan kegiatan operasional telah terlaksana secara efektif, efisien, dan ekonomis. Apabila belum dilaksanakan seperti seharusnya, maka auditor akan memberikan rekomendasi atau saran agar pada masa yang akan datang dapat dilakukan perbaikan ke arah yang lebih baik. Salah satu bagian penting dalam perusahaan yang perlu dilakukan audit operasional adalah sistem siklus pendapatan. Siklus pendapatan dikatakan penting karena dapat mempengaruhi tingkat kenaikan laba perusahaan. Siklus pendapatan yang tidak dikelola dengan baik akan menyebabkan proses penjualan dan penerimaan kas tidak terorganisir dengan baik yang kemudian dapat memberikan potensi akan terjadinya kecurangan atau kesalahan, baik kesalahan disengaja maupun tidak disengaja dalam proses penjualan dan penerimaan kas. Tentu saja pada akhirnya akan memberikan kerugian yang bersifat material kepada perusahaan. Setiap perusahaan pasti menginginkan perusahaannya untuk dapat terus berjalan (going concern) di mana kelangsungan hidup perusahaan berpusat pada penghasilan perusahaan yang secara otomatis berpusat pada proses penjualan. Penelitian ini dilakukan pada perusahaan PT New Inti Furnindo Cabang Bandung sebagai perusahaan perusahaan swasta yang bergerak dalam bidang perdagangan furnitur yang memiliki masalah dalam hal pencapaian target penjualan.

Tujuan yang ingin dicapai dalam penelitian ini adalah: (1) untuk memahami siklus pendapatan pada PT New Inti Furnindo Cabang Bandung; (2) untuk melaksanakan audit operasional terhadap siklus pendapatan pada PT New Inti Furnindo Cabang Bandung; (3) untuk mengetahui berbagai kelemahan pada sistem pengendalian yang dijalankan perusahaan terhadap siklus pendapatan sehingga dapat memberikan rekomendasi atas penerapan sistem pengendalian yang lebih baik, efektif, efisien, dan ekonomis di masa yang akan datang. Manfaat yang diharapkan dari penelitian ini adalah: (1) dapat memberikan rekomendasi kepada pihak manajemen untuk perbaikan siklus pendapatan di masa yang akan datang; dan (2) dapat menambah pengetahuan dan wawasan tentang audit operasional yang bertujuan untuk menilai efektifitas, efisiensi dan ekonomisasi.

\section{Pengertian Efektivitas, Efisiensi, dan Ekonomis}

Menurut Bayangkara (2008), pengertian efektif, efisien, dan ekonomis adalah: (1) efektif, yaitu tingkat keberhasilan suatu perusahaan untuk mencapai tujuannya. Apakah pelaksanaan suatu program atau aktivitas telah mencapai tujuannya. Efektivitas merupakan ukuran dari output; (2) efisien, berhubungan dengan bagaimana perusahaan melakukan operasinya, sehingga dicapai optimalisasi penggunaan sumber daya yang dimiliki. Efisien berhubungan dengan metode kerja; (3) ekonomis, berhubungan dengan bagaimana perusahaan dalam mendapatkan sumber daya yang akan digunakan dalam setiap aktivitas

\section{Tahapan Audit Operasional}

Menurut Reider (2002), audit operasional memiliki beberapa tahap yaitu: (1) merencanakan pelaksanaan audit operasional; (2) menetapkan tujuan dan objek audit operasional; (3) menganalisis struktur organisasi perusahaan; (4) menganalisa kebijaksanaan dan prosedur perusahaan; (5) menganalisis sistem keuangannya salah satunya adalah anggaran penjualan; (6) mengidentifikasikan area yang bermasalah; (7) membuat hasil pelaporan berupa kondisi, kriteria, sebab, akibat, dan rekomendasi; (8) membuat kesimpulan atas permasalahan yang terjadi beserta rekomendasinya; dan (9) melaporkan kepada pihak manajemen perusahaan atas segala permasalahan yang terjadi dan memberikan laporan rekomendasi yang dapat membantu manajemen untuk memperbaiki permasalahan perusahaan saat itu dan di masa yang akan datang. 


\section{METODE}

Jenis dari risetnya adalah riset eksploratoria. Dimensi waktu riset adalah cross sectional. Kedalaman risetnya berupa studi kasus dan studi literatur. Metode pengumpulan data dilakukan dengan cara langsung dan tidak langsung yaitu secara langsung berupa wawancara, pembagian kuesioner, dan secara tidak langsung berupa data arsip. Lingkungan penelitian yang dilakukan adalah lingkungan non-contived setting atau lingkungan riil. Unit analisisnya adalah sebuah perusahaan di bidang perdagangan. Metode pengumpulan data adalah melalui wawancara.

\section{HASIL DAN PEMBAHASAN}

Tujuan dari audit adalah untuk mencari bukti yang mendukung temuan dari setiap masalah yang ada dalam perusahaan dan memberikan rekomendasi demi perbaikan di masa yang akan datang. Objek dari audit operasional ini adalah target penjualan tahunan perusahaan yang tidak pernah tercapai, dilihat dari tingkat penjualan yang telah ditetapkan dan dibandingkan dengan tingkat penjualan yang sebenarnya. Objek penelitian yang akan diteliti secara fokus adalah data pada tahun 2009. Namun, untuk hasil penelitian yang terbaik maka, peneliti juga melakukan penelitian terhadap data pada tahun-tahun sebelumnya yaitu tahun 2007 dan 2008 (data terdapat di lampiran). Data pada tahun-tahun sebelumnya digunakan sebagai dasar penelitian terhadap perkembangan tingkat perusahaan. Dari penelitian tersebut dapat disimpulkan bahwa target penjualan selalu tidak tercapai.

Struktur organisasi perusahaan dilihat dari sumber daya manusianya, masing - masing fungsi kinerjanya, dan otorisasinya. Standar Operasional Perusahaan (SPO): dilihat dari kepatuhan, efektivitas, dan efisiensi. Sistem perencanaan audit Penelitian yang akan dilakukan terhadap PT New Inti Furnindo cabang Bandung adalah penelitian jangka pendek yaitu hanya fokus terhadap seluruh transaksi penjualan pada tahun 2009 dan sedikit data tingkat penjualan pada tahun 2007 dan 2008 untuk memperkuat hasil penelitian.

Tahap Pemeriksaan terinci : Tingkat Penjualan yang Tidak Mencapai Target

FERKRMRANGAN PEMRELIAN,PENJUAI_AN, TRANSFER TH ZII9

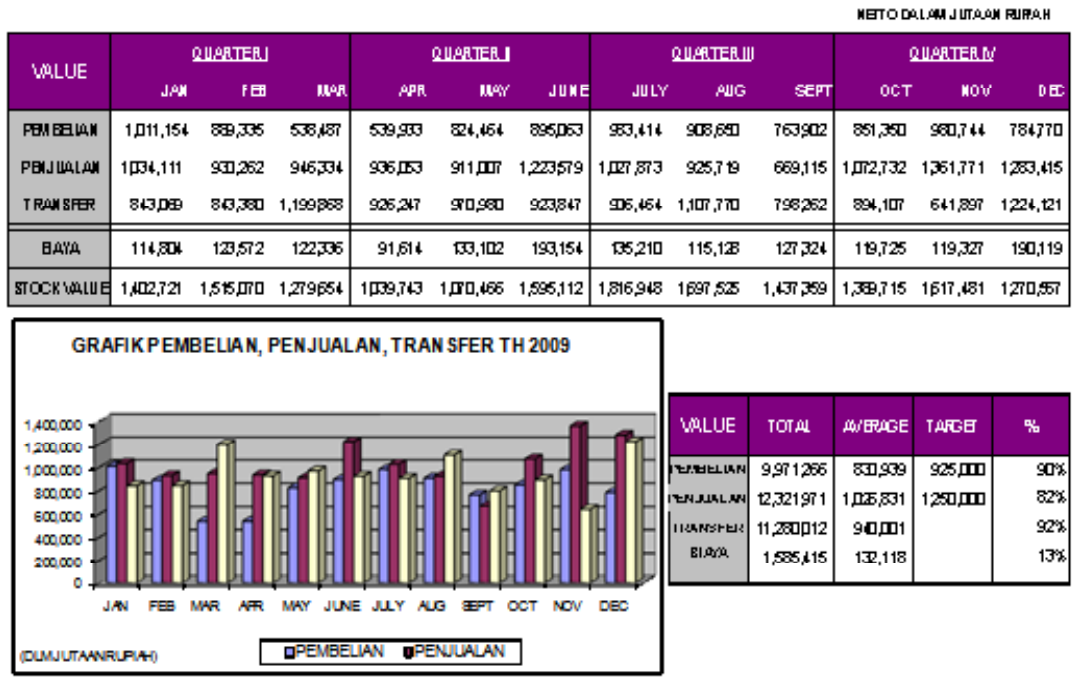

Gambar 1 Business Plan tahun 2009 
Diketahui berdasarkan penelitian yang telah dilakukan bahwa hasil penjualan PT New Inti Furnindo cabang Bandung selama tahun 2009 sebagian besar tidak mencapai target dan kurang memuaskan. Kondisi yang terjadi adalah, Pada bulan pertama sampai pada bulan ke - sepuluh tahun 2009, tingkat penjualan PT NIF selalu berada dibawah target. Kriteria yang ditetapkan adalah target penjualan perusahaan dalam sebulan harus dapat mencapai Rp 1.250.000.000. Sebab timbulnya kondisi ini adalah Perusahaan menentukan target penjualan terlalu tinggi pada bulan-bulan biasa. Telah diteliti melalui laporan salesman bahwa pada bulan-bulan biasa seperti awal tahun sampai dengan bulan oktober untuk bidang furnitur memiliki pasaran yang agak sepi karena tidak ada event tertentu bagi konsumen untuk membeli furnitur baru. Biasanya pangsa pasar yang membeli furnitur pada bulan-bulan tersebut sebagian besar adalah pasangan pengantin baru yang sedang ingin mengisi rumah baru dengan furnitur baru, badan usaha yang ingin mengisi furnitur baru di kantor baru, dan perseorangan yang ingin mengganti furniturnya yang telah rusak dengan furnitur yang baru.

Harga produk yang ditentukan PT NIF tergolong lebih rendah daripada perusahaan furnitur yang lain. Tujuan perusahaan untuk memberi harga murah adalah agar produk dapat terjual banyak tanpa memperhitungkan keuntungan yang didapat. Perusahaan hanya mementingkan produk laku dipasaran dalam jumlah yang banyak. Perusahaan hanya mengambil keuntungan sebesar $35 \%$ dari setiap harga jual, itupun belum dikurangi dengan diskon $20 \%$ yang diberikan oleh perusahaan ke setiap toko. Perusahaan jarang melakukan pameran sebagai ajang promosi sehingga konsumen masih belum begitu mengenal produk dari PT NIF. Adapun pameran yang ingin diadakan perusahaan sebaiknya difokuskan hanya pada bulan November dan Desember karena hanya pada bulan-bulan tersebutlah konsumen lebih antusias membeli produk furnitur. Apalagi dengan hanya memfokuskan pameran pada akhir tahun dapat menghemat biaya pameran tapi mempunyai potensi dalam meningkatkan tingkat penjualan.

Dari observasi juga diketahui bahwa salesman kurang termotivasi dalam melakukan penjualan dikarenakan komisi yang didapat salesman sangat kecil yaitu hanya $4 \%$ dari harga jual. Apalagi gaji salesman hanya berkisar Rp 1.200 .000 dan salesman tidak mendapatkan bonus apapun apabila penjualannya dapat mencapai target yang ditentukan. Salesman juga tidak mendapatkan sanksi apapun apabila penjualannya tidak mencapai target yang ditentukan. Pada saat ditugaskan untuk ke toko konsumen, salesman tidak mendapatkan dana tambahan dari perusahaan agar salesman tidak malas mengunjungi toko konsumen. Sales hanya mendapatkan uang bensin karena itu salesman terkadang suka menyelewengkan waktu dengan cara mengaku telah melakukan penawaran ke toko padahal pulang ke rumah. Akibat yang timbul adalah : kinerja Perusahaan dinilai tidak baik karena tingkat penjualan selalu di bawah target penjualan. Hal ini dapat menyebabkan beberapa investor yang ingin berinvestasi di perusahaan ini menjadi kurang yakin. Juga di mata konsumen, perusahaan dinilai memiliki produk yang kurang bagus. Padahal bukan di situ permasalahannya. Menentukan nilai harga yang terlalu rendah dapat mempengaruhi secara material terhadap pendapatan perusahaan. Pendapatan yang kecil akan menyulitkan perusahaan di masa yang akan datang dalam kelangsungan hidupnya.

Rekomendasi yang diberikan oleh auditor untuk masalah ini adalah untuk bidang usaha furnitur yang tidak selalu ramai pengunjung apalagi di bulan-bulan biasa sebaiknya perusahaan tidak menentukan target penjualan yang terlalu tinggi, karena furnitur termasuk barang mewah yang tidak dapat dibeli setiap hari oleh konsumen. Alangkah bijaknya jika perusahaan dapat menentukan target penjualan yang berbeda sesuai dengan bulan-bulan yang diminati konsumen untuk membeli furnitur. Sebaiknya perusahaan menentukan target penjualan Pada bulan Januari ditetapkan sebesar Rp 1.000.000.000. Awal tahun diprediksikan dapat mencapai angka satu miliar dikarenakan biasanya pada awal tahun baru banyak konsumen yang membeli furnitur baru dengan alasan mengisi rumah baru, suasana baru, atau mengganti furnitur yang telah rusak. Walaupun pasar sudah sedikit menurun dibandingkan dengan akhir tahun lalu. Misal : Ambil rata - rata harga dari harga tertinggi Rp 3.225.000 dan harga terendah Rp 250.000 yaitu Rp 3.225.000 + Rp 250.000 = Rp 3.475.000 dibagi $2=$ Rp 1.737.500 $\rightarrow$ sebagai harga tengah Jika target penjualan yang ingin dicapai Rp 1.000.000.000 / 
bulan dengan harga Rp 1.737.500, maka barang yang harus dijual agar mencapai target adalah sebanyak 575 item / bulan. Artinya dalam sehari perusahaan harus menjual 19 item/hari.

Pada bulan Februari-Mei target penjualan dapat mencapai Rp 900.000.000. Pada bulan kedua sampai dengan bulan kelima dapat diprediksikan pasaran mulai menurun karena tidak ada event khusus bagi konsumen untuk membeli furnitur baru. Jika target penjualan yang ingin dicapai Rp 900.000.000/bulan dengan harga tengah misalkan Rp 1.737.500, maka barang yang harus dijual agar mencapai target adalah sebanyak 518 item/bulan. Artinya dalam sehari perusahaan harus menjual 17 item/hari.

Pada bulan Juni-Juli target penjualan dapat mencapai Rp 1.000.000.000. Pada bulan Juni dan Juli ini hasil penjualan dapat kembali meningkat karena pada pertengahan tahun adalah high season dimana masa-masa liburan telah tiba dan konsumen mempunyai kesempatan untuk membeli furnitur baru. Namun, tingkat penjualan tidak dapat terlalu tinggi dikarenakan pada bulan-bulan tersebut sebagian besar konsumen berlibur ke luar kota atau ke luar negeri. Hal tersebut dapat mempengaruhi pangsa pasar. Sama seperti pada bulan Januari apabila target penjualan yang ingin dicapai Rp 1.000.000.000/bulan dengan harga Rp 1.737.500, maka barang yang harus dijual agar mencapai target adalah sebanyak 575 item/bulan. Artinya dalam sehari perusahaan harus menjual 19 item/hari.

Pada bulan Agustus-Oktober target penjualan dapat mencapai Rp 800.000.000. Pada bulan Agustus sampai dengan Oktober ini dapat dikatakan sebagai masa-masa sulit untuk bidang furnitur karena jarang sekali ada konsumen yang membeli furnitur pada range bulan ini. Oleh sebab itu, maka sebaiknya perusahaan menentukan target yang lebih rendah di range bulan ini. Jika target penjualan yang ingin dicapai Rp 800.000.000/bulan dengan harga tengah misalkan Rp 1.737.500, maka barang yang harus dijual agar mencapai target adalah sebanyak 460 item/bulan. Artinya dalam sehari perusahaan harus menjual 15 item/hari.

Temuan kedua adalah mengenai Biaya Operasional Tidak Sesuai Anggaran. Kondisi bahwa biaya yang dikeluarkan selalu melebihi anggaran yang telah ditetapkan. Kriteria yang ditetapkan oleh perusahaan adalah anggaran pengeluaran biaya berkisar antara Rp 106,806,580/bulan atau dibulatkan menjadi Rp 107.000.000/bulan. Untuk biaya setahun, perusahaan mengganggarkan sebesar Rp 1.284.000.000. Sebab dari biaya operasional yang lebih dari anggaran adalah prosedur pengeluaran kas dari perusahaan terlalu mudah dan kurangnya pengawasan. Proses pengeluaran kas hanya memerlukan tanda tangan dari PLM dan alasan pengeluaran kas tidak harus didasarkan atas nota/faktur/laporan pengeluaran kas, melainkan hanya dengan secara lisan ingin melakukan pembiayaan dan memerlukan kas keluar.n Hal ini sebaiknya diwaspadai walaupun setelah diteliti perbedaan antara anggaran dan biaya aktual tidak terlalu besar, namun apabila tidak diperbaiki segera maka akan menjadi celah bagi siapapun untuk melakukan kecurangan. Hal ini akan mengakibatkan pendapatan perusahaan menurun atau bisa jadi merugi dan dapat mempengaruhi kelangsungan hidup perusahaan untuk waktu jangka panjang. Rekomendasi yang diberikan auditor adalah diperlukan adanya tanda tangan Kepala Cabang apabila ingin mengeluarkan kas. Juga alasan pengeluaran kas harus jelas dan berdasarkan dokumen tertulis rincian mengenai apa saja yang perlu dibayar oleh perusahaan. Jika ada karyawan yang diketahui melakukan kecurangan baik perorangan maupun berkelompok maka akan dikenakan skorsing atau langsung dipecat.

Tahap pemeriksaan terinci berikutnya adalah atas struktur organisasi, dimana ditemukan kondisi banyaknya jabatan atau wewenang karyawan yang tugasnya kurang jelas karena ada beberapa yang fungsinya sama, seperti marketing dan salesman. Kriteria struktur organisasi yang baik seharusnya mencakup pembagian tugas dan wewenang secara jelas antar karyawan sehingga prosedur kinerja dapat dilakukan secara bertahap dan terorganisir. Struktur organisasi yang baik akan menghasilkan hasil kinerja yang baik dan adanya laporan pertanggungjawaban atas setiap kinerja yang dilakukan oleh karyawan. Hal yang menyebabkan adalah pembuatan struktur organisasi oleh manajemen perusahaan kurang terpikirkan dengan baik. Kurangnya pemahaman karyawan atas 
pekerjaan yang harus dilakukan juga para karyawan lebih sering menggunakan cara sendiri dalam bekerja dan tidak mengikuti struktur organisasi yang benar karena dianggap lebih efisien dan praktis untuk para karyawan. Hal ini mengakibatkan strukur organisasi yang ada pada perusahaan sangat tidak efisien dan efektif dimana adanya jabatan yang sebenarnya tidak seharusnya ada dalam perusahaan seperti: marketing. Struktur organisasi yang telah dibuat menjadi tidak berfungsi karena karyawan bekerja tidak sesuai struktur organisasi. Prosedur yang harusnya dilaksanakan sesuai dengan fungsi struktur organisasi menjadi tidak berjalan dengan baik.

Atas temuan ini auditor merekomendasikan bahwa seharusnya ada jabatan supervisor dimana dibawah perintah PLM namun dapat mengawasi hasil kerja sales agar pekerjaan salesman lebih dapat diawasi dan terkendali. Jabatan marketing sebaiknya ditiadakan dan diganti dengan General Manager yang mengawasi seluruh pekerjaan salesman, supervisor, dan PLM. Dimana keseluruhan pekerjaan diharuskan memberikan laporan kepada General Manager dan segala dokumen yang berhubungan dengan surat perintah maka harus dibubuhkan tanda tangan salah satunya oleh General Manager sebagai tanda tanggung jawab dan persetujuannya. Seharusnya Jabatan General Manager tidak setingkat dengan bagian akunting dan gudang, melainkan mempunyai posisi diatas mereka dan tepat dibawah Kepala Cabang. Dapat disebut juga General Manager sebagai asisten Kepala Cabang karena Kepala Cabang tidak harus langsung turun tangan untuk menangani masalah dalam perusahaan. Semua masalah ditangani oleh GM terlebih dahulu sebelum sampai ke Kepala Cabang agar pekerjaan bawahan dapat lebih terkendali. Jadi, bagian akunting dan bagian gudang juga dalam pengawasan General Manager dan jika terjadi masalah maka Kepala Cabang hanya akan meminta pertanggungjawaban dari General Manager tanpa harus menunjuk siapa yang terkait.

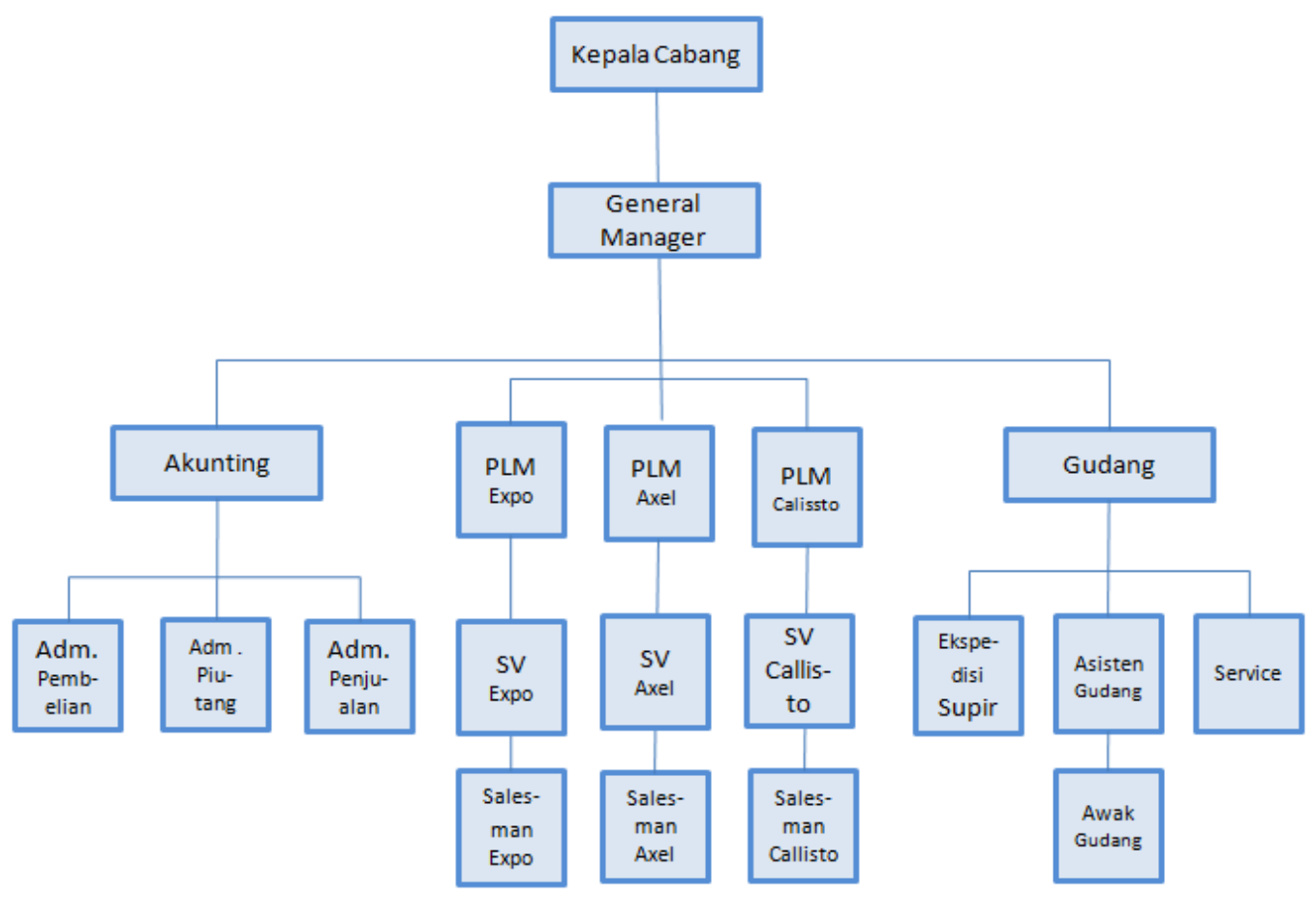

Gambar 1 Struktur organisasi yang direkomendasikan 
Tahap pemeriksaan terinci terakhir adalah mengenai uraian tugas karyawan dimana ditemukan kondisi Karyawan bekerja sesuai dengan kewajiban dan tanggung jawab yang mereka buat sendiri karena mereka anggap lebih efisien dan praktis. Kriteria yang ditetapkan adalah bahwa setiap karyawan harus bekerja sesuai dengan fungsi dan tugas yang telah ditentukan sesuai dengan jabatannya masing-masing. Sebab yang mendasari adalah karena kurangnya pengawasan dari atasan. Karyawan tidak pernah diberikan hukuman jika melakukan kesalahan, kecuali tidak hadir selama tiga hari berturut-turut tanpa keterangan yang jelas, maka baru dikenakan skorsing. Demikian pula karyawan yang tidak mencapai target tidak diberikan sanksi, sementara karyawan yang mencapai target juga tidak diberikan reward, semuanya hanya dihitung dari komisi

Akibat yang terjadi adalah prosedur perusahaan yang seharusnya berjalan dengan baik menjadi berantakan dan tidak sesuai prosedur. Banyak kesalahan yang terjadi oleh karyawan dan mengakibatkan kerugian bagi perusahaan. Sales dan marketing sering melakukan pekerjaan yang sama. Awak gudang jarang sekali kelihatan bekerja karena tenaganya tidak diperlukan. Kepala Cabang jarang membubuhkan tanda tangannya pada laporan karena tidak pernah dimintai tanda tangan karena Kepala Cabang terlalu sibuk sehingga kurang dapat mengurusi bawahannya.

Rekomendasi yang diberikan auditor adalah perlu diadakannya pengendalian berkala terhadap kinerja karyawan dan jika diketahui ada yang melakukan pelanggaran atau bekerja tidak sesuai dengan prosedur perusahaan dan tidak melakukan kewajjiban dan tanggung jawabnya dengan baik, maka akan diberikan sanksi berupa SP (Surat Peringatan) atau skorsing.

\section{PENUTUP}

Tingkat penjualan yang rendah dan tidak dapat mencapai target penjualan yang telah ditetapkan oleh perusahaan karena kesalahan penetapan target penjualan yang benar oleh perusahaan. Walaupun kuantitas penjualan produk perusahaan banyak, namun pendapatan yang diterima perusahaan tidak meningkat dan tidak banyak, dan biaya operasional yang dikeluarkan oleh perusahaan selalu lebih besar dari yang telah dianggarkan. Karyawan yang bekerja pada perusahaan tidak bekerja sesuai dengan prosedur perusahaan, fungsi kerja marketing dan salesman kurang lebih sama sehingga terjadi pekerjaan ganda dan kurang efektif dalam hasil kinerjanya. Selain itu, perusahaan melakukan pemborosan dalam hal mengeluarkan gaji ganda karena fungsi kerja yang sama tersebut. Proses penjualan dan penerimaan kas tidak sesuai dengan standar operasional perusahaan. Produk hasil produksi yang dikirim dari pusat yang seharusnya dicek terlebih dahulu oleh bagian gudang, tetapi seringkali tidak dicek dan langsung dikirim ke alamat konsumen. Hal ini menyebabkan banyaknya retur dari konsumen karena kerusakan barang dan kesalahan warna yang dipesan konsumen. Juga sering terjadi kesalahan pengiriman produk konsumen dapat disebabkan karena kesalahan supir yang mengantarkan barang tidak sesuai dengan alamat yang tercantum, kesalahan bagian penjualan dalam mencatat alamat yang konsumen, kesalahan bagian gudang bila terjadi penggantian alamat pesanan konsumen, dan kesalahan konsumen memberikan alamat yang benar (hal ini diluar tanggung jawab perusahaan). Dokumen-dokumen perusahaan sebagai bukti atas telah terjadinya transaksi penjualan dan penerimaan kas tidak lengkap sehingga transaksi-transaksi yang terjadi tidak dapat dipertanggungjawabkan kebenarannya.

\section{Saran}

Penetapan target penjualan sebaiknya diturunkan pada bulan-bulan biasa karena pada umumnya di bulan-bulan biasa konsumen jarang melakukan pembelian. Apalagi jika dilihat dari jenis produk yang dijual oleh perusahaan adalah produk menengah ke atas yang penggunaannya bersifat jangka panjang karena tidak dapat habis dalam waktu yang singkat. Setelah melakukan penelitian terhadap grafik penjualan perusahaan dan target pasar, maka penetapan target penjualan yang baik 
adalah: (1) Bulan Januari: Minimum Rp 1.000.000.000 ; (2) Bulan Februari-Mei: Minimum Rp 900.000.000 ; (3) Bulan Juni-Juli: Minimum Rp 1.000.000.000 ; (4) Bulan Agustus-Oktober: Minimum Rp 800.000.000. Bulan paling sepi untuk bidang usaha furnitur adalah bulan Agustus dan Oktober, karena itu penetapan target penjualan harus lebih rendah. (5) Untuk Bulan NovemberDesember (high season): Minimum Rp 1.250.000.000, tidak ada perubahan karena perusahaan dapat mencapai target pada bulan-bulan ini.

Peningkatan harga jual produk dari $35 \%$ dari modal + biaya produksi menjadi 50\% dari modal + biaya produksi. Pemberian diskon hanya dilakukan pada bulan-bulan high season atau pada saat pameran. Dapat juga pemberian diskon untuk bulan-bulan biasa, namun dengan kondisi adanya transaksi penjualan dalam jumlah yang cukup besar yaitu sekitar Rp 20.000.000 dalam satu transaksi. Pemberian diskon diturunkan dari 20\% menjadi maksimal 10\%. Untuk penurunan pemberian diskon dapat diganti dengan pemberian merchandise berupa topi, kalender, kaos, pulpen, atau gelas cantik agar konsumen tetap tertarik walau pemberian diskon sudah tidak sebesar terdahulu. Peningkatan komisi menjadi 6\% dari harga jual produk bagi salesman yang dapat mencapai target penjualan. Diberikannya dana tambahan seperti uang transportasi dan uang makan kepada karyawan yang bertugas melakukan kunjungan ke toko konsumen untuk melakukan penawaran agar karyawan lebih bersemangat melakukan tugas kunjungan. Bagi salesman yang tingkat penjualannya dapat mencapai target perusahaan selama setahun berturut-turut akan diberikan cuti tambahan selama seminggu. Dibuatnya sanksi bagi salesman yang penjualannya tidak mencapai target yang telah ditentukan perusahaan. Juga bagi karyawan yang kinerjanya dianggap tidak mendukung kemajuan perusahaan.

Sanksi dapat berupa: (1) tidak ada komisi bagi salesman yang tingkat penjualannya di bawah target; (2) bagi salesman yang tingkat penjualannya selalu tidak mencapai target dalam waktu maksimal 3 bulan berturut-turut, maka akan dikenakan SP 1; (3) bagi salesman yang tingkat penjualannya selalu tidak mencapai target dalam waktu maksimal 5 bulan berturut-turut, maka akan dikenakan SP 2; (4) bagi salesman yang tingkat penjualannya selalu tidak mencapai target dalam waktu maksimal 6 bulan berturut-turut, maka akan dipecat; (5) tidak adanya uang transportasi dan makan bagi karyawan yang melakukan kunjungan penawaran ke toko konsumen jika karyawan diketahui telah menyalahgunakan waktu yang diberikan untuk melakukan penawaran dengan cara pergi ke tempat lain selain ke toko konsumen. Pembatasan penggunaan kas perusahaan untuk hal-hal yang tidak terlalu penting, seperti: penghematan penggunaan alat tulis, penghematan bahan bakar kendaraan. Untuk itu kendaraan perusahaan harus dipergunakan sebaik mungkin hanya untuk urusan perusahaan saja, dan penghematan biaya pameran. Oleh karena itu, sebaiknya perusahaan hanya melakukan pameran pada saat bulan-bulan tertentu yang dianggap ramai pembeli.

Perubahan struktur organisasi seperti: menghapus jabatan marketing yang fungsinya kurang lebih sama dengan salesman, lalu menambahkan posisi General Manager untuk mengatur dan mengawasi keseluruhan bagian akunting, PLM, dan bagian gudang yang berkaitan dengan siklus pendapatan. Hal ini bertujuan agar kinerja karyawan lebih terawasi dan terorganisasi dengan baik. Perbaikan dalam hal pembuatan laporan setiap kinerja yang dilakukan juga pencatatan dokumen yang berkaitan dengan transaksi penjualan dan penerimaan kas, agar transaksi yang terjadi dapat dibuktikan dan dipertanggung jawabkan kebenarannya melalui dokumen yang ada. Produk hasil produksi yang dikirim dari pusat harus segera dicek kualitasnya terlebih dahulu oleh bagian gudang sebelum pada akhirnya disimpan di gudang dan dikirim ke alamat konsumen. Produk dicek apakah produk sudah sesuai dengan pesanan konsumen atau belum. Sebelum pada akhirnya produk dikirimkan ke alamat konsumen, alamat yang tercantum harus dicek terlebih dahulu oleh bagian gudang agar tidak terjadi kesalahan pengiriman. Tanda tangan Kepala Cabang sangat wajib ada dalam setiap dokumen penting yang berhubungan dengan transaksi penjualan, penerimaan kas, juga setiap biaya yang akan dikeluarkan agar transaksi yang terjadi tetap terkontrol dan dapat dipertanggungjawabkan kebenarannya. 


\section{DAFTAR PUSTAKA}

Bayangkara, IBK. Audit manajemen prosedur dan implementasi. Jakarta: Salemba Empat

Reider, R. (2002). Operational review. New Jersey: John Wiley and Sons.

Sawyer. (2005). Internal audit. Jakarta: Salemba Empat.

Tunggal, W. A. (2002). Struktur pengendalian intern. Jakarta: Rineka Cipta. 